\title{
Ethical Values In Indonesian Character Building
}

\author{
Drs. Indri Djanarko, M. H. \\ Pancasila Lecturer in Universitas Dr. Soetomo Surabaya \\ Rommel Utungga Pasopati, S. Hub. Int. \\ Graduate Student of Driyarkara School of Philosophy Jakarta
}

\begin{abstract}
Today, character building is one way to form a good human personality according to moral values. Education is formed within the framework of formal education curriculum at school. The Ministry of Education established eighteen values of character based on individual and social values both theoretically and practically. Meanwhile, these values must face the reality of crime, corruption, juvenile delinquency, and even immature sexuality. The problem is that these values seem too rigid to apply even though the lists consist of good values. There is the most important value above all; ethical intention to others. By using the qualitative method, this paper would like to emphasize on ethical deeds by Nicolaus Driyarkara as one is invited to be responsible to others. That responsibility is a duty as a manifestation of conscience. To the extent that one acts with respect for the existence of others, his actions are ethical. Humans are inter-subjective beings; his individuality depends on otherness. Such dependence triggers sympathy up to empathy which is not harmful but liberates human beings. In education, there is a process of hominization as being human and humanization as becoming human which could be reflected in today's Indonesian character building. In conclusion, the character will be wellformed not because it is educated by values, but because it understands values. The value is ethical to others, from the context of family, society, to state.
\end{abstract}

Keywords - character building, conscience, ethics, moral values

\section{INTRODUCTION}

Today, character building is one way to form a good human personality according to moral values. Education then is used to shape such characters on students [1]. Meanwhile, a human is known as a character built through a process in social constructions. This condition also reflects Indonesian students today as entities who embrace their everyday life. They live with parents, friends, and other circumstances too. They are not just things that could easily be shaped trough other values. In this point, character building in school is known as values of life that are important to be taught to students for their thoughts about their various conditions.

In another way, the process has to face challenges in juvenile delinquency. At one point, values of students in their everyday life are considered enough to face such challenges. Living with families is the main perspective on understanding life. At another point, character building is needed to shape students to prepare them to face the broader world. Living values should also be completed with teaching values. It seems that family and school have to work together to shape the characters. However, juvenile delinquency is increasingly embraced by students. It seems that character building is not enough to state what is good and bad. There is ethics as the main idea of character which is ignored in the process. So, how could ethical values be explained in Indonesian character building? Showing the importance of ethical values will tell us that building a character is not by enriching ourselves but by putting more intention and attention to others. By understanding others, we will understand our selves. Thus students will be ready to know wider circumstances beyond them.

\section{THE VALUES OF INDONESIAN CHARACTER BUILDING}

Indonesian character building talks about morality as the solution for today's moral crisis in Indonesian nuances [2]. The moral nuances are now at the intersection between moral concept and moral behavior. The moral concept states what is good based on various customs embraced by societies and voice of conscience in knowing what is categorically good or bad in Kantian senses. In Indonesia, Pancasila is the main source of such morality in which it is used to live in coexistence with others. Besides the concept, moral behavior is a practice of morality in how the concept is actualized in everyday life [3]. It is more relative than the concept. So, a character is between what is morally known and what is morally practised.

The Ministry of Education established eighteen values of character based on national culture ranging from religious, honest, tolerant, disciplined, hard work, creative, independent, democratic, curiosity, nationalism, patriotism, respect for achievement, friendship, peace, love to read, environmental care, social care, friendship, and responsibility [4]. Those values are reflected from Pancasila applied through education. The values are explained in how a character should be the core of education to reach religious, nationalism, integrity, independence, and gotongroyong points in today's era [5]. Those points are also stated as guidelines to live as good students, children, and also citizens. 
The above establishment shows background and future of characters which Indonesian government would like to achieve. The background is what is already known in Indonesian character individually and socially. The points are the emphasis on the Indonesian values because those points are not new to people since they are living with the ideas. The future is what is wanted to be known in Indonesian character. Indonesian government still thinks that the eighteen points are remained needed for further generations as the problems persist too. Many problems which students face could be overcome by embracing those values as identities. By emphasizing the values, again and again, students are reminded over and over again about what is good and bad conceptually and categorically.

There is nothing new in those eighteen points. There is such refutation on those points since people already knew the ideas. The idea of bringing it into school curriculum is also normal since its systemic view may teach students categorically. From time to time, the problems remain the same and even getting worse. Character building still could not prevent students to do such bad things. There is such a big gap between background and future of the character building. It does not omit the precious elements of the values but the essential part of why the values should be known needed to be explored furthermore.

\section{ETHICAL INTENTIONS TO OTHERS AS CHARACTER}

The eighteen values are based on individual and social values both theoretically and practically. Meanwhile, these values must face the reality of crime, corruption, juvenile delinquency, to premature sexuality. These values seem too rigid to apply even though the lists consist of good values. There is the most important value above all; ethical intention to others. It is the gap which has been talked in the previous subchapter. Knowing that the values are good is not enough for students to understand why these are important for them. Students should understand why they should have such characters in their life besides merely learning how to behave according to the rigid points.

In ethical deeds by Nicolaus Driyarkara, one is invited to be responsible to others as see in existentialism and Levinasian sense. That responsibility is a duty as a manifestation of conscience [6]. To the extent that one acts with respect for the existence of others, his actions are ethical. This existential view relates human beings as 'himself' relates to 'others'. In 'himself', human lives in the world through own values. They already know what is good and bad by embracing values [7]. Meanwhile, in 'other self', knowing others also means understanding their self since both of them are equal to each other. This paradox shows that human beings could live by themselves as long as they also regard others as human too. Therefore, intention to own beings also relates to understanding to other beings.

As being responsible to others, essentially and practically, ethical intention to others are the main ideas of the eighteen points. The main theme is not exploring own self but building it towards otherness. By putting the main relations to otherness, students could consider whether their deeds may hurt others or not. Human beings are not just individual but personas. These personas, according to Driyarkara, are spiritual souls who go beyond physical images of people [8]. By going beyond physical, people can intend their deeds towards others. Human beings are not just beings but being-for-others. Humans are inter-subjective beings; his individuality depends on otherness. Such dependence triggers sympathy up to empathy which is not harmful but liberates human beings.

Moreover, character building should be built from inside as realization of the intention of others. The inside condition is conscience which directs people as outside condition in good actions. The conscience also takes a role as a limitation from inside in what is categorically considered as good and bad, and restriction from outside in how others are a continuation of own deeds. Conscience is the consciousness or awareness in relations to others [9]. As long as people know that any action is directed towards others, they also know that others should be considered as themselves. The eighteen points reflect the conscience of people because character building is a process of both exploring ourselves and understanding others. Students should build a character which is understood through learning of ethical consequences of others.

Driyarkara considered education as an open, dynamic, and active reality of students [10]. This view could also relate knowledge in how he realizes conscience in education. Driyarkara proposed hominization (derived from homo as a human) and humanization in education as a continuation of student education [11]. Hominization relates to being human, a process which shapes human as himself. This is a minimal view of character building. Humanization is becoming human, a process which shapes human furthermore including understanding others as bigger entities than self. This view is more positive since humanization does not tell what students have to do but acknowledges them about others. In today's character building, humanization should be done beyond hominization. Students should not be entirely taught, but they should learn it by themselves. Ethical intentions towards others are the main corridor in showing students that their actions may affect others. In this logic, others are the subjects too so that appreciating others in their otherness is important in having necessary character today. 


\section{ETHICAL VALUES IN CHARACTER BUILDING}

Character building is about ethics rather than exploring own self. A character should be directed not only to enriching own abilities but also varying perspectives of others. This analogy reflects that students do not have to fortify themselves by those eighteen points, but those points are understood as ideas to go to wider societies. Students should appreciate others as they understand themselves. A character should bring in better actions from sympathy to further empathy reflected from humanity and inter-subjective values.

Building character is not to apply such absolute points for students. A character is not educated but understood, as a moral crisis is not to be eliminated by force but understood by a meaningful knowledge of conscience [12]. Therefore, telling students to have such character is useless unless they are provided with examples so that they could understand it by themselves. Students should know that they fully control their actions in their characters since they have free will to do so. Ethical intention to others should be understood not as an obligation or absolute compulsory but ethical willingness. Students may know what is good categorically but more important is how they will do that.

Indonesian character building should also make students know about themselves furthermore. The character building should not put students into such mould for expected outcome. Students could not be expected to be things because every one of them has their characteristics and circumstances. Education could provide examples for students about otherness and inter-subjective relations. Only by doing so then character building is ethical for students and others.

\section{CONCLUSION}

A character will be well-formed not because it is educated by values, but because it understands values. The value is ethical to others, from the context of family, society, to state. The eighteen points brought by Indonesian government should also consider ethical intention towards others. By considering otherness, characters could be responsible to others, build sympathy to empathy, and sustain the conscience. By understanding the ethical intention of others, students could understand themselves better too.
A'raf Vol. XIII, No. 1, January - June 2016, 2016, pp. 129.

[2] Rosidin, Negeri Semarak Pendidikan Karakter, http://opini.fajarnews.com/read/2016/08/12/1 2495/negeri.semarak.pendidikan.karakte

r, Accessed on July 25 ${ }^{\text {th }} 2017,2016$.

[3] Rosidin, 2016.

[4] Rosidin, 2016.

[5] Kementerian Pendidikan dan Kebudayaan RI, Karakter Sebagai Poros Pendidikan. http://cerdasberkarakter.kemdikbud.go.id/\#sli der, Accessed on July 25 ${ }^{\text {th }} 2017,2017$.

[6] Banin Diar Sukmono, "Etika Driyarkara dan Relevansinya di Era Postmodern", Jurnal Filsafat, Vol. 23, No. 1, April 2013, 2013, pp. 81-82.

[7] Nicolaus Driyarkara, Filsafat Manusia, Yogyakarta: Kanisius, 1969, pp. 9.

[8] Driyarkara, 1969:13.

[9] Sukmono, 2013:80.

[10] Aziz, 2016:137.

[11] Nicolaus Driyarkara, Karya Lengkap Driyarkara; Esai-Esai Pemikiran yang Terlibat Penuh dalam Perjuangan Bangsanya. Jakarta: Gramedia, 2006, pp. 376.

[12] Driyarkara, 2006:357.

\section{References}

[1] Asep Rifqi Abdul Aziz, "Konsep Hominisasi dan Humanisasi Menurut Driyarkara", Al- 